\title{
Morpho-anatomical analysis of Aspidosperma olivaceum and A. polyneuron, Apocynaceae
}

\author{
Fernanda Lisot Krentkowski, ${ }^{1}$ Márcia do Rocio Duarte ${ }^{*, 2}$ \\ 'Programa de Pós-graduação em Ciências Farmacêuticas, Universidade \\ Federal do Paraná, Brazil, \\ ${ }^{2}$ Laboratório de Farmacognosia, Departamento de Farmácia, Universidade \\ Federal do Paraná, Brazil.
}

\begin{abstract}
The family Apocynaceae includes many medicinal species, such as Aspidosperma olivaceum Müll. Arg. and A. polyneuron Müll. Arg. The first, popularly known as "peroba-branca", is a source of indole alkaloids that are recognized for their antitumor activity. The second, known as "peroba-rosa", is used by some people for treating malaria. To contribute to the knowledge about Brazilian medicinal plants and potential vegetal drugs, a morpho-anatomical analysis of the leaves and stems of these tree species was carried out. The botanical material was fixed, sectioned and stained using standard techniques. Histochemical tests were performed and the material was also analyzed using a scanning electron microscope. Aspidosperma olivaceum and A. polyneuron are morphologically similar, both presenting alternate, simple, elliptic-lanceolate leaves. The leaves are hypostomatic with anomocytic stomata and have non-glandular trichomes. In the stem, there are peripheral phellogen, lignified fibers and some stone cells in the cortex and pith, as well as numerous gelatinous fibers near the phloem. Prismatic calcium oxalate crystals and laticifers are present in the leaves and stems. Unlike A. olivaceum, A. polyneuron also has cyclocytic stomata, predominantly unicellular non-glandular trichomes and a biconvex midrib with a sharper curve on the adaxial side. In addition, A. olivaceum differs because it has some idioblasts with phenolic content.
\end{abstract}

Received 7 Dec 2011

Accepted 20 Feb 2012

Available online 12 Apr 2012

ISSN 0102-695X http://dx.doi.org/10.1590/S0102$695 \times 2012005000044$

\section{Introduction}

Apocynaceae are among the ten largest families of Angiosperms, with approximately 400 genera in two subfamilies, Apocynoideae and Plumerioideae, and 3700 species. They are predominantly distributed in the tropics and subtropics, but also occur in temperate regions (Barroso, 1991; Joly, 1998; Souza \& Lorenzi, 2005).

The genus Aspidosperma Mart. \& Zucc., which is native to the Americas, is found in Brazil, Mexico and Argentina (Corrêa, 1984; Souza \& Lorenzi, 2005), includes trees with latex (Markgraf, 1968) and is widely known for its high quality wood and use in traditional medicine (Botsaris, 2007; Oliveira et al., 2009). In Brazil, Aspidosperma olivaceum Müll. Arg., popularly known as "guatambu", "peroba" or "peroba-branca", is found in the Atlantic Forest from Minas Gerais to Santa Catarina (Flora Brasiliensis, 1906). This tree is a source of the indole alkaloids olivacine and ellipticine that are known for their antitumor activity (Ohashi \& Oki, 1996; Oliveira, 1999; Barbosa et al., 2003; Costa, 2005; Pereira et al., 2007). Aspidosperma polyneuron Müll. Arg., a related species that is commonly known as "peroba-rosa", is a tree that is locally used as astringent, antipyretic, antidiarrheal and especially as anti-malarial agent (Botsaris, 2007), and studies have proven the antimicrobial effect of its leaves, stems and roots (Ferreira et al., 2003; Granato et al., 2005).

Based on the promising phytochemical and pharmacological results of studies about $A$. olivaceum and $A$. polyneuron, the objective of the present work was to elucidate the morpho-anatomy of the leaves and stems of these medicinal plants to contribute to what is known about the Brazilian flora and to characterize them macroand microscopically because of their potential use as vegetal drugs.

\section{Material and Methods}

\section{Plant material}

Samples of leaves and stems of Aspidosperma olivaceum Müll. Arg. and A. polyneuron Müll. Arg., Apocynaceae, were collected from cultivated plants growing in the sun at the Horto Municipal da Barreirinha,

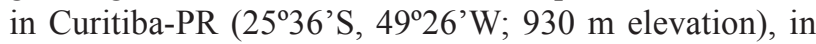


June 2009. These species were identified by taxonomists at the Museu Botânico Municipal de Curitiba, in the Jardim Botânico Francisca Maria Garfunkel Richbieter in Curitiba-PR (voucher numbers MBM 352341 and MBM 352342, respectively).

\section{Methodology}

Morphological descriptions of the leaves were based on the classification proposed by Hickey (1974) and measurements were made from at least ten leaves, to calculate the average dimensions.

Fragments of mature leaves and young stems, obtained between 5 and $25 \mathrm{~cm}$ from the caulinar apex, were fixed in FAA 70 (Johansen, 1940) and stored in 70\% (v/v) ethanol (Berlyn \& Miksche, 1976). Freehand sections (transverse and longitudinal, including paradermal) of the fixed material were made into semipermanent slides. The dyes used were astra blue and basic fuchsine (Roeser, 1972). Permanent slides of the fixed material were also made by dehydrating the material in an ethanol series and embedding it in glycol methacrylate (Feder \& O'Brien, 1968). The material was sectioned using a rotary microtome and the sections were stained with toluidine blue (O'Brien et al., 1964). Histochemical tests were carried out with Wagner's reagent for alkaloids (Furr \& Mahlberg, 1981), ferric chloride for phenolic compounds (Johansen, 1940), Sudan III for lipophilic substances (Sass, 1951), hydrochloric phloroglucin for lignin (Foster, 1949), lugol solution for starch (Berlyn \& Miksche, 1976) and diluted sulfuric acid to reveal the chemical nature of the calcium crystals (Oliveira et al., 1991).

The ultrastructural analysis of the leaf surface (Souza, 1998) was performed using a scanning electron microscope. Samples were fixed, dehydrated in an ascending ethanol series, critical point dried with $\mathrm{CO} 2$, attached to stubs and sputter coated with gold.

\section{Results}

Both species have similar morpho-anatomical characters that consist of alternate, simple leaves, which are symmetrical, coriaceous, elliptic-lanceolate, with acute apex, acute and decurrent base, and entire margin (Figures 1A, 3A). The adaxial surface is bright dark green in comparison with the clearer, opaque abaxial surface. The average size of the leaves of $A$. olivaceum is 7.5 (4.5$9.5) \times 2.3(1.6-2.8) \mathrm{cm}$ and the average size of the leaves of A. polyneuron is $5(4.5-5.5) \times 1.3(1-1.5) \mathrm{cm}$. The average petiole lengths are $0.9 \mathrm{~cm}$ and $0.5 \mathrm{~cm}$, respectively.

The venation is pinnate, with a midrib that gives rise to the secondary veins, and is subclassified as camptodromous-brochidodromous, which means that the secondary veins form a series of prominent arcs instead of terminating at the margin.
In face view, the epidermis has cells with practically straight anticlinal walls on both surfaces and is coated with a smooth cuticle (Figures 1B-D, 3B-D). The leaves are hypostomatic, with anomocytic stomata (Figures 1C, 3D). In A. polyneuron, cyclocytic stomata are also found. On the leaves, there are simple non-glandular trichomes that are unicellular or multicellular and have a slightly granular cuticle, thick cell walls and acute apex (Figures 1D, 3B). The distribution of the trichomes is denser on the petiole than on the blade. In A. olivaceum, some multicellular trichomes have a wider apical cell in relation to the basal one. The trichomes of $A$. polyneuron are predominantly unicellular.

Transverse sections show that the epidermis is uniseriate and coated with a thick cuticle that forms cuticular flanges. The cells of the adaxial surface are comparatively larger than the cells of the abaxial side and the stomata occur on the same level as the other epidermal cells (Figures 1E, 3E).

The mesophyll is dorsiventral and comprised of one to three strata of palisade cells and approximately ten layers of spongy parenchyma, making it about $70 \%$ of the height of the chlorenchyma (Figures 1E, 3E). Minor collateral vascular bundles with sclerenchymatic caps adjoining the xylem and phloem are distributed in the mesophyll (Figures 1E, 3E). Laticifers containing alkaloids, lipophilic and phenolic substances are present, and in A. olivaceum it is found few parenchymatic cells with phenolic content.

The midrib is biconvex, and the curvature on the adaxial surface is sharper in A. polyneuron (Figures $1 \mathrm{~F}$, $3 \mathrm{~F}$ ). The epidermis of this region consists of one stratum of cells with convex outer periclinal walls. The cuticle is thick and inserted among the cells forming the same cuticular flanges (Figure 1G). The palisade parenchyma is gradually interrupted and then there is annular collenchyma (Figure 1G) composed of about six layers near the adaxial surface and four strata on the abaxial side (Figures 1F, $3 \mathrm{~F})$. In the collenchyma and ground parenchyma, it is encountered laticifers, fibers with thick cell walls and reduced lumen, some stone cells and prismatic calcium oxalate crystals (Figures $1 \mathrm{G}, \mathrm{H}, 3 \mathrm{~F}$ ). There is only one bicollateral vascular bundle, which forms an open arc and is surrounded by a practically continuous sclerenchymatic sheath (Figures 1F, 3F). The midrib of A. olivaceum also has some idioblasts with phenolic compounds.

The petiole, in transverse section, is circular to biconvex with a uniseriate epidermis and non-glandular trichomes similar to those previously described (Figures 2A, C, 4A, B). The vascular bundle is bicollateral and forms an open arc (Figures 2A, 4A). In A. olivaceum, there are fibers in different stages of lignification (Figure 2B) and a starch sheath encircling the vascular system. Laticifers, fibers, stone cells and prismatic calcium oxalate crystals mainly occur in the ground parenchyma. 
In A. olivaceum, few idioblasts with phenolic compounds are also noted.

The stem is circular in transverse section (Figure 4C). At the level analyzed, it has a persistent epidermis and peripheral phellogen (Figures 2F, 4D). Some nonglandular trichomes that are similar to those on the leaves are also present. In the cortex, it is found annular collenchyma, cortical parenchyma and stone cells. Fibers with thick lignified cell walls and reduced lumen occur in the outer cortex and pith (Figure 2F). Numerous gelatinous fibers (Figures 2D, E, 4C, D) are encountered in the vicinity of the vascular system, which consists of groups
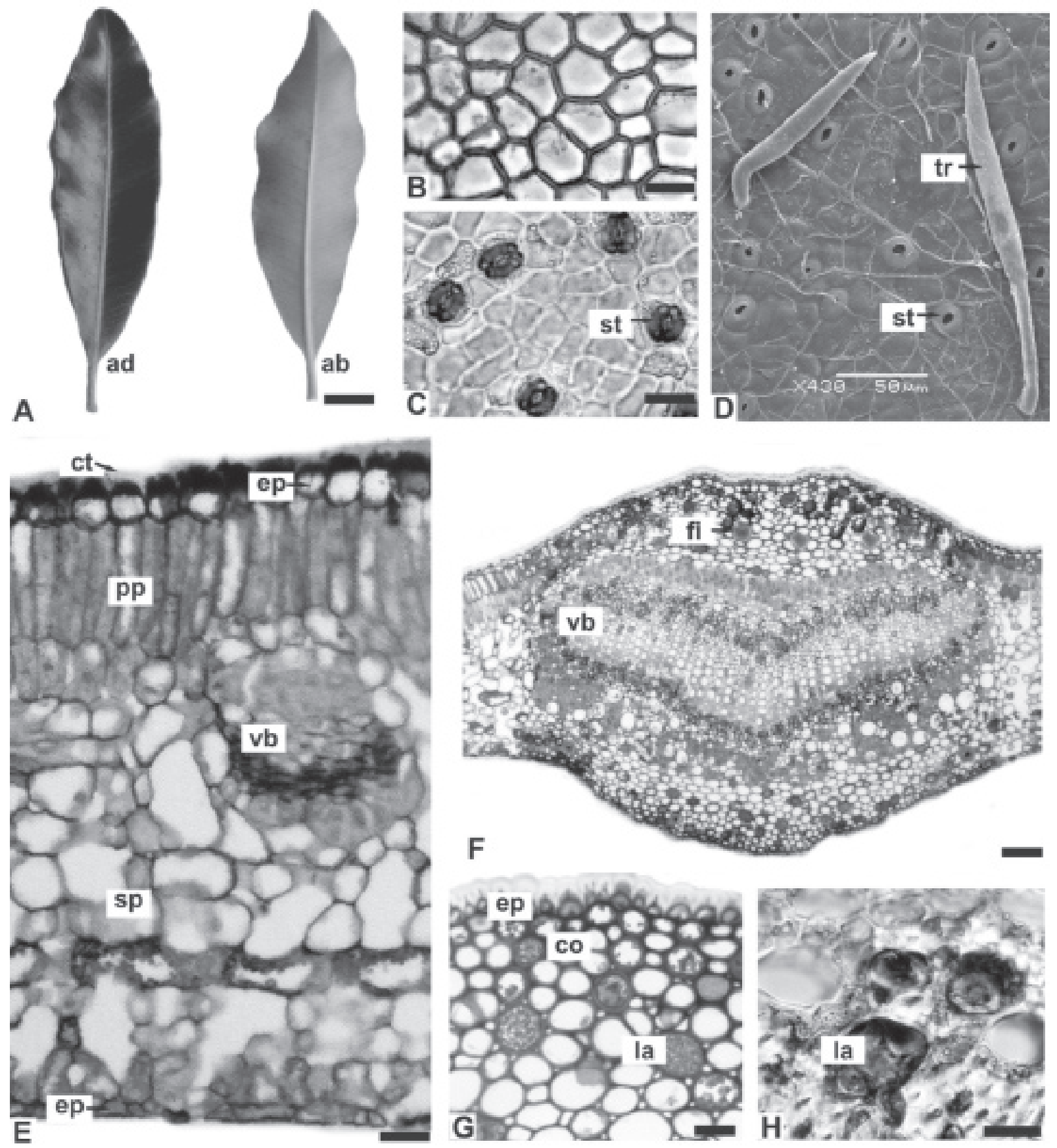

Figure 1. Aspidosperma olivaceum Müll. Arg., Apocynaceae - leaf: A. General aspect; B, C. Face view of the adaxial and abaxial sides of the epidermis, respectively; D. Abaxial side of the epidermis in SEM, revealing smooth cuticle, stomata and non-glandular trichomes; E. Transverse section of the intervein region of the blade, showing dorsiventral mesophyll; F. Transverse section of the midrib; G. Detail of the midrib, indicating collenchyma and laticifers; H. Pormenor of the previous figure. Abbreviations: ab: abaxial side; ad: adaxial side; co: collenchyma; ct: cuticle; ep: epidermis; fi: fiber; la: laticifer; pp: palisade parenchyma; SEM: scanning electron microscopy; sp: spongy parenchyma; st: stomatum; tr: non-glandular trichome; vb: vascular bundle. Bar:1 cm (A), $20 \mu \mathrm{m}(\mathrm{B}, \mathrm{C}, \mathrm{E}, \mathrm{G}, \mathrm{H}), 100 \mu \mathrm{m}(\mathrm{F})$. 

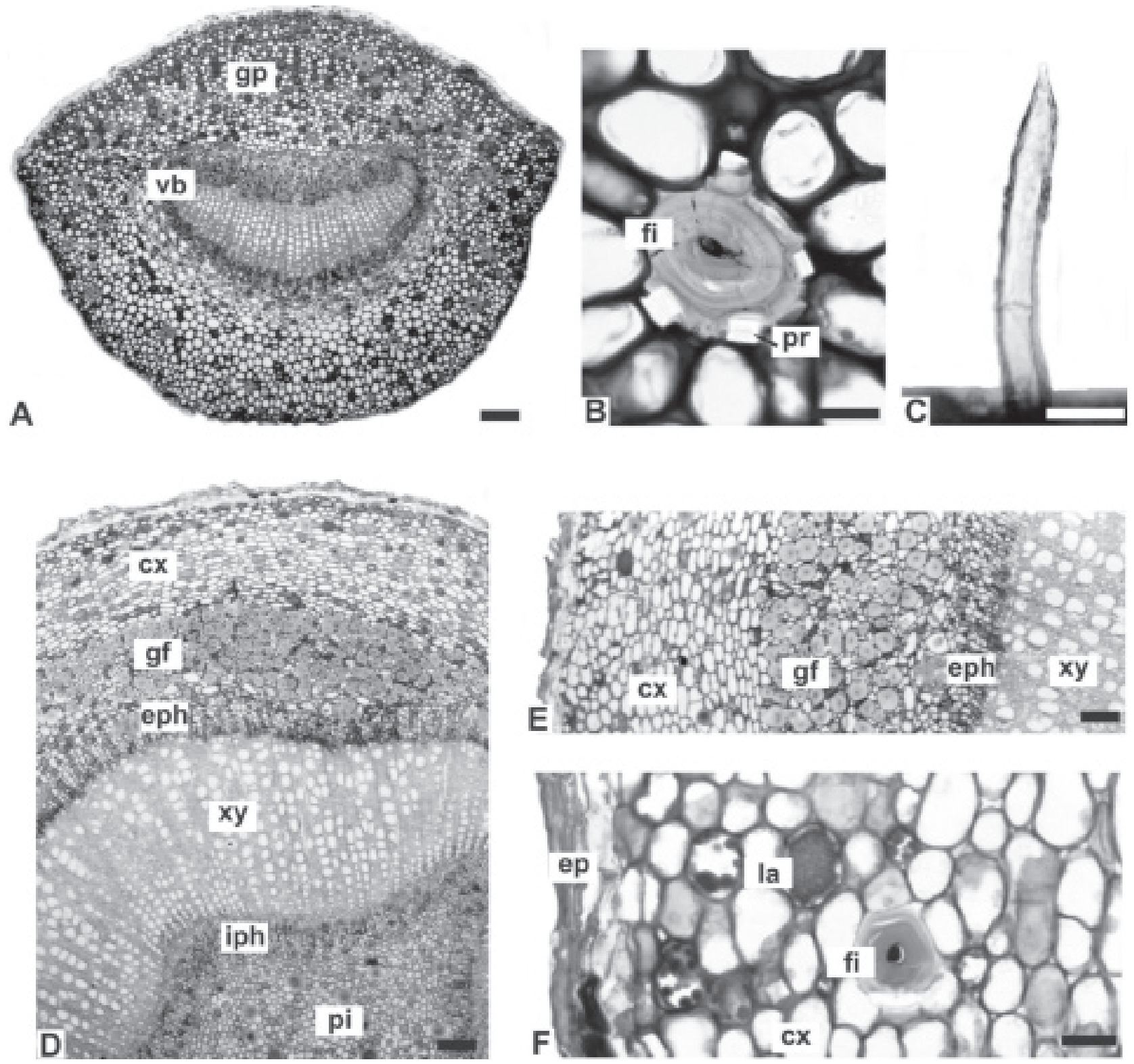

Figure 2. Aspidosperma olivaceum Müll. Arg., Apocynaceae - petiole and stem: A. Transverse section of the petiole; B, C. Details of the previous figure, showing fiber, prismatic calcium oxalate crystals and multicellular non-glandular trichome; D. Overall organization of the stem in transverse section; E, F. Pormenor of the previous figure; Abbreviations: cx: cortex; ep: epidermis; eph: external phloem; fi: fiber; gf: gelatinous fiber; gp: ground parenchyma; iph: internal phloem; la: laticifer; pi: pith; pr: prismatic crystal; vb: vascular bundle; xy: xylem. Bar: $20 \mu \mathrm{m}$ (B, C, F), $50 \mu \mathrm{m}(\mathrm{E}), 100 \mu \mathrm{m}$ (A, D). 

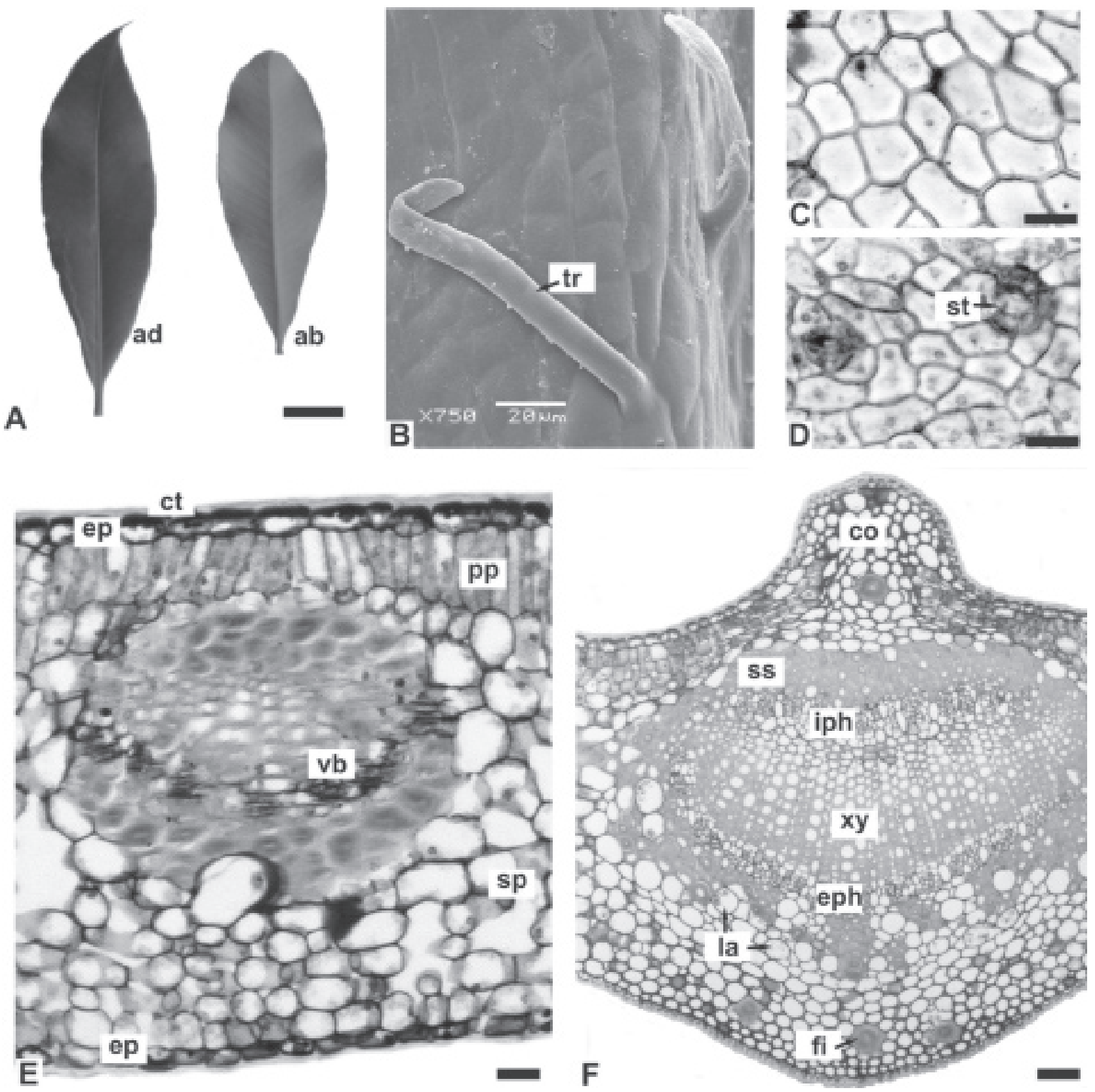

Figure 3. Aspidosperma polyneuron Müll. Arg., Apocynaceae - leaf: A. General aspect; B. Non-glandular trichomes and smooth cuticle on the adaxial surface of the epidermis, in SEM; C, D. Face view of the adaxial and abaxial sides of the epidermis, respectively; E. Transverse section of the blade showing dorsiventral mesophyll and a minor collateral vascular bundle; F. Transverse section of the midrib revealing the sharp curvature of the adaxial side. Abbreviations: ab: abaxial side; ad: adaxial side; co: collenchyma; ct: cuticle; ep: epidermis; eph: external phloem; fi: fiber; iph: internal phloem; la: laticifer; pp: palisade parenchyma; SEM: scanning electron microscopy; sp: spongy parenchyma; ss: sclerenchymatic sheath; st: stomatum; tr: non-glandular trichome; vb: vascular bundle; xy: xylem. Bar: $1 \mathrm{~cm}(\mathrm{~A}), 20 \mu \mathrm{m}(\mathrm{C}, \mathrm{D}, \mathrm{E}), 50 \mu \mathrm{m}(\mathrm{F})$. 


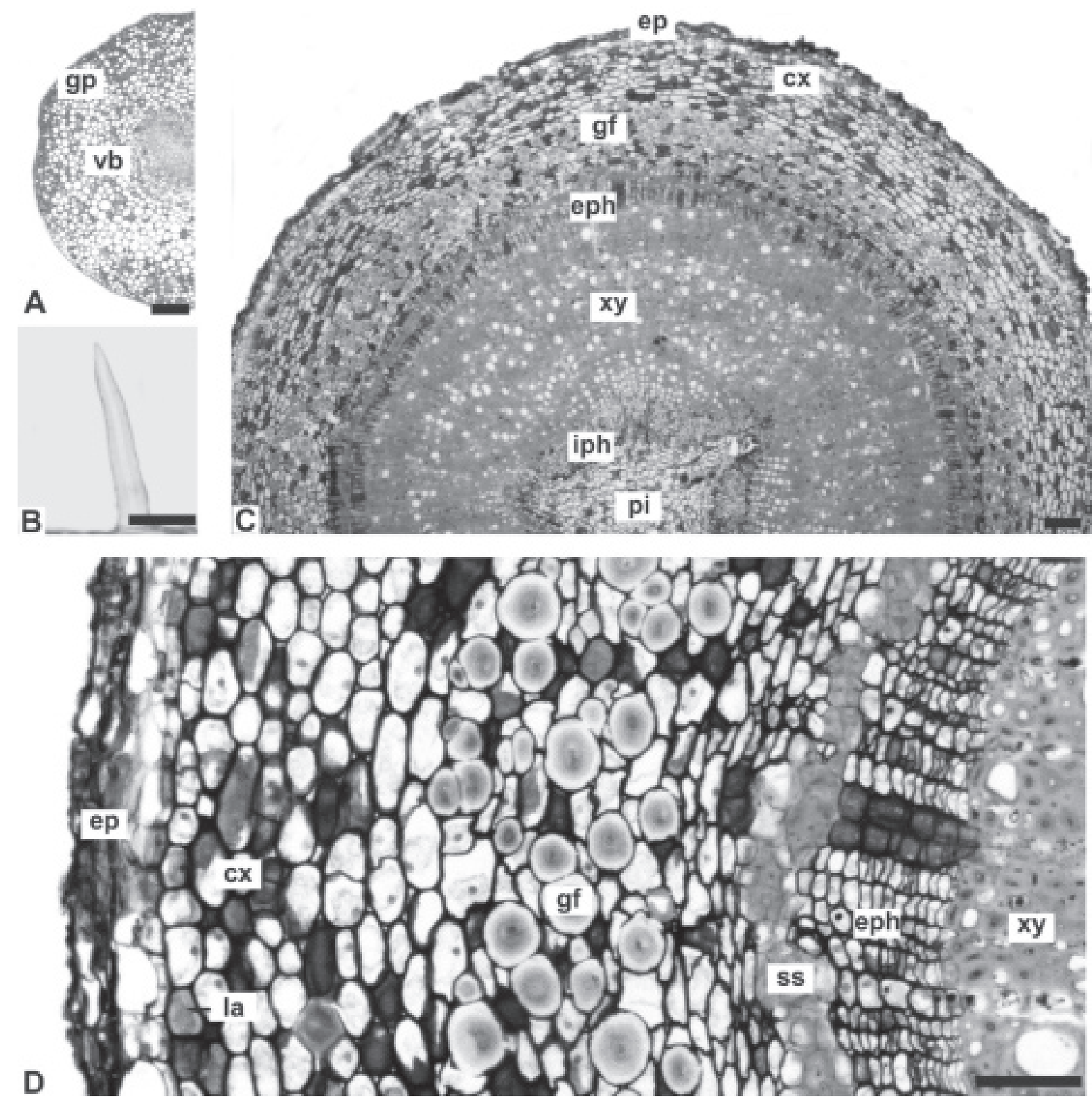

Figure 4. Aspidosperma polyneuron Müll. Arg., Apocynaceae - petiole and stem: A. Transverse section of the petiole; B. Unicellular, non-glandular trichome of the petiole; C. Overall aspect of the stem in transverse section; D. Detail of the previous figure. Abbreviations: cx: cortex; ep: epidermis; eph: external phloem; gf: gelatinous fiber; gp: ground parenchyma; iph: internal phloem; la: laticifer; pi: pith; ss: sclerenchymatic sheath; vb: vascular bundle; xy: xylem. Bar: $20 \mu \mathrm{m}$ (D), $50 \mu \mathrm{m}(\mathrm{B}), 100 \mu \mathrm{m}(\mathrm{A}, \mathrm{C})$.

of lignified fibers, external phloem, xylem and internal phloem (Figures 2D, E, 4C, D). Laticifers (Figure 2F) and prismatic calcium oxalate crystals are also present. In $A$. olivaceum there are some phenolic idioblasts as well.

\section{Discussion}

Considering the external morphological appearance of leaves of Apocynaceae, Aspidosperma olivaceum and A. polyneuron have aspects of those found within the family and genus (Markgraf, 1968), such as leaves that are simple and alternate, and blades that are symmetrical, elliptic-lanceolate, and coriaceous with entire margin. In comparison, similar characters were found by Albuquerque (1971) for $A$. carapanauba Pichon, A. marcgravianum Woodson and A. oblongum A. DC.

Regarding the leaf venation, which is considered an important characteristic because it is constant within a taxonomic group of plants (Mauseth, 1988), the venation 
found in the family is normally pinnate and subclassified as camptodromous-brochidodromous (Mohan \& Inamdar, 1982). This type was verified in the two species studied. In another study, Quinet \& Andreata (2005) noted that $A$. parvifolium A. DC. and A. pyricollum Müll. Arg have the camptodromous pattern in contrast to craspedodromous venation found in A. compactinervium Kuhlm.

As for the remaining morpho-anatomical aspects investigated, A. olivaceum and A. polyneuron have common characters found in other representatives of the genus, such as leaf epidermal cells with practically straight anticlinal walls, thick and smooth cuticle that forms cuticular flanges, anomocytic stomata (or predominantly this type) restricted to the abaxial surface, non-glandular trichomes, dorsiventral mesophyll, bicollateral vascular bundle, sclereids, prismatic calcium oxalate crystals and laticifers. In general, these characters are present in A. carapanauba, A. marcgravianum, A. oblongum, A. excelsum Benth. (Albuquerque, 1971), A. parvifolium, A. pyricollum (Quinet \& Andreata, 2005), A. spruceanum Benth. ex Müll. Arg., A. desmanthum Benth. ex Müll. Arg. (Reis, 2008) and A. nitidum Benth. (Añez, 2009).

Some differences occur among Aspidosperma species, for example, A. carapanauba and $A$. excelsum have striated cuticle, $A$. desmanthum has calcium oxalate druses (Reis, 2008), A. nitidum possesses paracytic stomata (Añez, 2009) and A. quebracho Griseb. has isobilateral mesophyll (Metcalfe \& Chalk, 1950). However, structural variations should be evaluated carefully because morphology can be environmentally influenced, such as the shape of the epidermal cells, cuticular ornamentation and the organization of the mesophyll (Cutter, 1986).

In species of Apocynaceae, trichomes can be glandular or non-glandular, simple or branched, and uniseriate or shortly unicellular (Metcalfe \& Chalk, 1988; Werker, 2000). Reis (2008) found multicellular, nonglandular, filiform trichomes which were ornamented with spines in A. carapanauba, A. desmanthum, A. excelsum and $A$. spruceanum, whereas Añez (2009) described the presence of short, non-glandular trichomes in A. nitidum. This data is similar to the results of the present study where unicellular and multicellular trichomes were found.

According to Metcalfe \& Chalk (1950), nonarticulated laticifers, with diversely colored exudates and associated with the vascular system, are typical for the family. Albuquerque (1971) confirmed this by noting that the leaves of $A$. marcgravianum and $A$. oblongum had non-articulated laticifers. However, subsequent studies included data that contradict this pattern, for example, Demarco et al. (2006) found the presence of articulated laticifers, with thick cell walls, in A. australe Müll. Arg. In addition, Reis (2008) described articulated laticifers, which had thin walls and varied in diameter, along the vascular bundles in the leaves of $A$. excelsum, A. desmanthum and $A$. spruceanum. In relation to $A$. carapanauba, contradictory results were published because Albuquerque (1971) found that this species had articulated laticifers and Reis (2008) found that the internal secretory structures of this species were not articulated. Although the present work did not determine the type of laticifers, the location of these structures near the vascular system in the two species studied is in accordance with the family. Based on various researches on latex, its composition is varied, consisting of alkaloids, proteins, phytosterols and fatty acids, and may be associated with pharmacological activities (Yoder \& Mahlberg, 1976; Furr \& Mahlberg, 1981; Endress \& Bruyns, 2000).

The young stems of $A$. olivaceum and $A$. polyneuron showed incipient secondary growth, and it was possible to distinguish the persistent epidermis and the superficial periderm that was being formed. In Apocynaceae, phellogen is generally peripheral (Metcalfe \& Chalk, 1950; Esau, 1974). The presence of prismatic calcium oxalate crystals, fibers and stone cells was also found in other species of the genus, such as A. quebracho (Metcalfe \& Chalk, 1950).

Although there are many similarities between A. olivaceum and A. polyneuron, the results of this study show that they can be distinguished based on the contour of the midrib and the type of predominant trichome. Aspidosperma polyneuron has a midrib in transverse section that is more acute on the adaxial surface, and also has a higher frequency of unicellular trichomes when compared with A. olivaceum. In addition, A. olivaceum has idioblasts with phenolic content. According to Scalbert (1991) and Beckman (2000), these cells can be part of the defense mechanisms of plants because they are toxic and astringent, which makes it difficult for herbivores to feed on the plants and makes the plants resistant to microorganisms. These metabolites also interfere on the taste and color of several vegetal species, being used in food industry for flavoring and dyeing. Besides, different therapeutic effects are attributed to them, such as expectorant, hepatoprotective, choleretic, anticholesteremic and analgesics, proving their pharmacological importance (Carvalho et al. 2007).

\section{Aknowledgements}

The authors express their gratitude to the Centro de Microscopia Eletrônica (UFPR) for the micrographs, the taxonomists of the Museu Botanico Municipal de Curitiba for the species identification and to the REUNIUFPR for the scholarship to FLK.

\section{References}

Albuquerque BWP 1971. Contribuição ao conhecimento das 
Aspidosperma da Amazônia Brasileira (Apocynaceae): Aspidosperma carapanauba Pichon, A. marcgravianun Woodson e A. oblongum A. DC. Acta Amaz 1: 9-20.

Añez RBS 2009. Análise morfoanatômica das folhas e casca de Aspidosperma nitidum Benth. e Aspidosperma marcgravianum Woodson (Apocynaceae) com abordagem farmacognóstica e etnofarmacológica. Manaus, 55p. Tese de Doutorado em Ciências Biológicas, Instituto Nacional de Pesquisas da Amazônia, Universidade Federal do Amazonas.

Barbosa WLR, Tavares ICC, Soares DC 2003. Alcalóides de Aspidosperma auriculatum Standl. Rev Bras Farmacogn 13: 6-8.

Barroso GM 1991. Sistemática de Angiospermas no Brasil. Viçosa: UFV Imprensa Universitária.

Beckman CH 2000. Phenolic-storing cells: keys to programmed cell death and periderm formation in wilt disease resistance and in general defence responses in plants. Physiol Mol Plant Pathol 7: 101-110.

Berlyn GP, Miksche JP 1976. Botanical microtechnique and cytochemistry. Ames: Iowa State University.

Botsaris AS 2007. Plants used traditionally to treat malaria in Brazil: the archives of flora medicinal. J Ethnobiol Ethnomed 3: 13-18.

Carvalho JCT, Gosmann G, Schenkel EP. Compostos fenólicos simples e heterosídicos. In Simões CMO, Schenkel EP, Gosmann G, Mello JCP, Mentz LA, Petrovick PR (Org.) Farmacognosia: da planta ao medicamento 6. ed. Porto Alegre/Florianópolis: UFRGS/UFSC, p. 519-535.

Corrêa MP 1984. Dicionário das plantas úteis do Brasil. Rio de Janeiro: Instituto Brasileiro de Desenvolvimento Florestal.

Costa FJC 2005. Estudo fitoquímico e busca de substâncias bioativas em Aspidosperma olivaceum (Müll.) Arg. e Malouetia arborea (Vell.) Miers. (Apocynaceae). Araraquara, 231p. Tese de Doutorado em Química, Instituto de Química, Universidade Estadual Paulista.

Cutter EG 1986. Anatomia vegetal: células e tecidos. 2 ed. São Paulo: Roca.

Demarco D, Kinoshita LS, Castro MM 2006. Laticíferos articulados anastomosados - novos registros para Apocynaceae. Rev Bras Bot 29: 133-144.

Endress ME, Bruyns PV 2000. A revised classification of Apocynaceae. Bot Rev 66: 1-56.

Esau K 1974. Anatomia das plantas com sementes. São Paulo: E. Blücher.

Feder N, O' Brien TP 1968. Plant microtechnique: some principles and new methods. Am J Bot 55: 123-142.

Ferreira DT, Silva-Junior JV, Soeira LS, Zanolli-Filho LA, Ishikawa NK, Barbosa AM, Yassumoto L 2003. Avaliação da atividade antifúngica dos extratos etanólicos de raiz, caule e folhas de Aspidosperma polyneuron. XI Encontro de Química da Região Sul. Pelotas, Brasil.

Flora Brasiliensis 1906. http://florabrasiliensis.cria.org.br, accessed Jul 2010.

Foster AS 1949. Practical plant anatomy. Princeton: D. Van Nostrand.

Furr M, Mahlberg PG 1981. Histochemical analyses of laticifers and glandular trichomes in Cannabis sativa. $J$ Nat Prod 44: 153-159.

Granato D, Nunes DS, Mattos PP, Rios EM, Glinski A, Rodrigues LC, Zanusso-Junior G 2005. Chemical and biological evaluation of rejects from the wood industry. Braz Arch Biol Techn 48: 237-241.

Hickey LJ 1974. Clasificación de la arquitectura de las hojas de dicotiledóneas. Bol Soc Argent Bot 16: 1-26.

Johansen DA 1940. Plant microtechnique. New York: McGrawHill Book.

Joly AB 1998. Botânica: introdução à taxonomia vegetal. 12 ed. São Paulo: Imprensa Nacional.

Markgraf F 1968. Apocináceas. In Reitz PR Flora Ilustrada Catarinense Itajaí: Herbário Barbosa Rodrigues, p. $1-112$.

Mauseth JD 1988. Plant anatomy. Menlo Park: Benjamin/ Cummings.

Metcalfe CR, Chalk L 1950. Anatomy of the dicotyledons: leaves, stem, and wood in relation to taxonomy with notes on economic uses. Oxford: Clarendon.

Metcalfe CR, Chalk L 1988. Anatomy of dicotyledons. Oxford: Clarendon Press.

Mohan JSS, Inamdar JA 1982. Leaf architecture of Apocynaceae. Proc Indian Acad Sci 91: 189-200.

O'Brien TP, Feder N, McCully ME 1964. Polychromatic staining of plants cell walls by toluidine blue $O$. Protoplasma 56: 368-373.

Ohashi M, Oki T 1996. Ellipticine and related anticancer agents. Expert Opin Ther Pat 6: 1285-1294.

Oliveira AJB 1999. Estudo de seis espécies do gênero Aspidosperma utilizando GC, GC/MS e HPLC: análise qualitativa e quantitativa. Teste autobiográfico; cultura de tecidos e células vegetais e rota de preparação de compostos diméricos ramiflorina $A$ e ramiflorina B. Campinas, 371p. Tese de Doutorado em Química Orgânica, Instituto de Química, Universidade Estadual de Campinas.

Oliveira F, Akisue G, Akisue MK 1991. Farmacognosia. São Paulo: Atheneu.

Oliveira VB, Freitas MSM, Mathias L, Braz-Filho R, Vieira IJC 2009. Atividade biológica e alcaloides indólicos do gênero Aspidosperma (Apocynaceae): uma revisão. Rev Bras Pl Med 11: 92-99.

Pereira MM, Jácome RLRP, Alcântara AFC, Alves RB, Raslan DS 2007. Alcalóides indólicos isolados de espécies do gênero Aspidosperma (Apocynaceae). Quím Nova 30: 970-983.

Quinet CGP, Andreata RHP 2005. Estudo taxonômico e morfológico das espécies de Apocynaceae Adans. na reserva Rio das Pedras, Município de Mangaratiba, Rio de Janeiro, Brasil. Pesquisas Bot 56: 13-74. 
Reis ARS 2008. Anatomia foliar e o xilema secundário de espécies de Aspidosperma Mart. \& Zucc. (Apocynaceae). Belém, 93p. Dissertação de Mestrado em Botânica Tropical, Universidade Federal Rural da Amazônia.

Roeser KR 1972. Die Nadel der Schwarzkiefer-Massenprodukt und Kunstwerk der Natur. Mikrokosmos 61: 33-36.

Sass JE 1951. Botanical microtechnique. Ames: Iowa State College.

Scalbert A 1991. Antimicrobial properties of tannins. Phytochemistry 30: 3875-3883.

Souza VC, Lorenzi H 2005. Botânica sistemática. São Paulo: Nova Odessa.

Souza W 1998. Técnicas básicas de microscopia eletrônica aplicadas às Ciências Biológicas. Rio de Janeiro: Sociedade Brasileira de Microscopia Eletrônica.

Werker E 2000. Trichome diversity and development. Adv Bot Res 31: 1-35.
Yoder LR, Mahlberg PG 1976. Reactions of alkaloid and histochemical indicators in laticifers and specialized parenchyma cells of Catharanthus roseus (Apocynaceae). Am J Bot 63: 1167-1173.

\section{*Correspondence}

Márcia do Rocio Duarte

Programa de Pós-graduação em Ciências Farmacêuticas, Universidade Federal do Paraná, Setor de Ciências da Saúde, Sede Botânico

Av. Pref. Lothário Meissner, 632, Jardim Botânico, 80210-170 Curitiba-PR, Brazil

marciard@ufpr.br

Tel. +554133604064

Fax: +554133604101 